\title{
Costs and effects of interventions targeting frequent presenters to the emergency department: a systematic and narrative review
}

\author{
Viola Korczak ${ }^{1,2^{*}}$ (D) Janani Shanthosh ${ }^{1,4}$, Stephen Jan ${ }^{1,3}$, Michael Dinh ${ }^{2}$ and Thomas Lung ${ }^{1,3}$
}

\begin{abstract}
Background: Previous systematic reviews have examined the effectiveness of interventions for frequent presenters to the Emergency Department (ED) but not the costs and cost-effectiveness of such interventions.

Method: A systematic literature review was conducted which screened the following databases: Pubmed, Medline, Embase, Cochrane and Econlit. An inclusion and exclusion criteria were developed following PRISMA guidelines. A narrative review methodology was adopted due to the heterogeneity of the reporting of the costs across the studies.

Results: One thousand three hundred eighty-nine papers were found and 16 were included in the review. All of the interventions were variations of a case management approach. Apart from one study which had mixed results, all of the papers reported a decrease in ED use and costs. There were no cost effectiveness studies.
\end{abstract}

Conclusion: The majority of interventions for frequent presenters to the ED were found to decrease ED use and cost. Future research should be undertaken to examine the cost effectiveness of these interventions.

Keywords: Emergency medicine, Frequent presenter, Health care costs, Health economics

\section{Background}

Patients who frequently present to the Emergency Department (ED) represent a population for whom additional and specific programs could potentially yield significant potential economic and health benefits. However there is currently no agreed definition of 'frequent presenter' and definitions vary widely $[1,2]$ from three $[3,4]$ to more than eight $[5]$ or ten $[6,7]$ presentations per year. Although frequent presenters to the ED have been found to be largely heterogeneous [8] [9], some generalisations can be made about this cohort. They are usually individuals who are from lower socio economic backgrounds [10] and are more likely to present with

\footnotetext{
* Correspondence: vkorczak@georgeinstitute.org.au

${ }^{1}$ The George Institute for Global Health, UNSW Sydney, Level 5/1 King St Newtown NSW, Sydney 2042, Australia

2Emergency Department, Royal Prince Alfred Hospital, Sydney, Australia Full list of author information is available at the end of the article
}

drug and alcohol [11], mental health [12] and chronic illnesses $[10,13,14]$.

Despite the need for services to address this cohort, there is limited evidence of effective interventions targeted at this group. Some that have been used in this setting include case management [15], cognitive behaviour therapy (CBT) [16], or social worker involvement [17]. Limited research has been conducted on evaluating the costs and cost-effectiveness of these interventions compared to other hospital interventions.

This is an important topic for several reasons. First, health care spending is increasing disproportionately. Spending on health in Australia has grown by about 50\% in real terms over the past decade compared with population growth of about $17 \%$ over the same period [18]. Emergency department use is on the rise and the causes are multifactorial, and include among other factors an ageing population and increase in chronic conditions [19]. Between 2012/2013 and 2016/2017 presentations

(c) The Author(s). 2019 Open Access This article is distributed under the terms of the Creative Commons Attribution 4.0 International License (http://creativecommons.org/licenses/by/4.0/), which permits unrestricted use, distribution, and reproduction in any medium, provided you give appropriate credit to the original author(s) and the source, provide a link to the Creative Commons license, and indicate if changes were made. The Creative Commons Public Domain Dedication waiver (http://creativecommons.org/publicdomain/zero/1.0/) applies to the data made available in this article, unless otherwise stated. 
to emergency departments in Australia increased by $3.7 \%$ on average each year [20]. Similar increases in emergency department use are evident in the USA [21]. Second, while frequent presenters may constitute a small percentage of the total of ED users they are often the most disadvantaged members of society [1]. In Australia for example, almost $24 \%$ of ED presentations are for patients living in the lowest SES groups [22].

The social determinants of health including income, education, employment and housing play a role in understanding this disadvantage, which is especially pertinent in the ED setting. One Canadian study found that homeless individuals have "greater than eight times the incidence of ED visits than their age and sex matched non homeless counterparts" [23]. Furthermore 50\% of acute care is administered to the uninsured, who are usually the most economically disadvantaged [24]. The social determinants of health including housing are relevant to the provision of emergency department care. From an economic perspective it is timely to review which programs are benefiting this vulnerable group in the hope that they may be rolled out to maximise positive health and social outcomes.

The main aim of this research is to review the economic evaluations of interventions aimed at frequent presenters and to assess their cost implications and costeffectiveness.

\section{Methods}

A systematic review of the literature was conducted to assess interventions for frequent presenters to the ED and the associated costs of the intervention programs outlined. PRISMA guidelines were used for this systematic review [25].

There were two inclusion criteria. First, interventions had to be aimed at 'frequent presenters' to the Emergency Department. The numerical definition of 'frequent presenter' as specifically defined in each paper was used. Second, the cost of the intervention had to be assessed. Papers were included from all countries and languages, in adult populations over 18 years of age and if the study included more than 10 subjects.

Studies were excluded if the intervention was not based in the ED, did not focus on frequent presenters or did not include any data on the cost of the intervention. Review and opinion pieces were excluded as were papers set in paediatric populations or studies that included fewer than 10 patients. "Systematic reviews were excluded from the literature search to ensure that this review did not 'double count' individual papers. Another reason is because even though some literature reviews did have cost data, it was often summarised in one paragraph and it was not possible to assess the costing data adequately". However we reviewed the bibliographies of literature reviews to ensure that relevant papers were not omitted.

A search was conducted in Pubmed, Medline, Embase, Cochrane and Econlit between June and December 2018. Grey literature was also reviewed and the reference lists of all relevant papers were screened. The following search terms was used in all databases: "(cost analysis OR cost effectiveness OR economic evaluation OR cost impact OR cost-benefit OR cost-utility) AND frequent* AND emergency". The only limit on the search was 'human'. There was no start date to the search and the end date was December 2018.

Two reviewers (VK and JS) independently reviewed the literature. Any discrepancies were resolved by a third independent reviewer (TL). An initial search of titles and then abstracts was carried out. Once abstracts were identified, the full texts of the papers were obtained and the final list for inclusion was decided. Data were independently extracted by the two reviewers (VK and JS) into a form in Excel developed prior to the review. Information on the year, country, setting, numerical definition of frequent presenter, interventions, comparator used in the study, healthcare system perspective, costs included, type of economic evaluation and outcome were included in the table. The reviewers met to verify that the extraction sheet was consistent. Any discrepancies in data extraction were resolved between the two reviewers. The reviewers (VK) and (JS) also assessed the papers using The Evidence Project risk of bias tool [26]. There was consensus between the authors on the quality of the papers and all the papers were included in the final analysis. The risk of bias table is included in the Additional file 1.

Once the table was completed it became evident that it was not possible to directly compare the outcomes of the studies due to the heterogeneity of reporting of the costs of the programs. A narrative review [27] was adopted and further tables were developed to synthesise the information on this topic.

\section{Results}

The search term yielded 1389 papers in total. Once the titles were screened, 160 abstracts were reviewed and 16 papers were included in the review. Figure 1 includes the PRISMA flowchart of the search results. Table 1 summarises the main outcomes from the literature review. Of the 16 papers included in the review, all the papers were in English. All of the studies were from the US except two from Sweden [28, 29] and one from Australia [30].

\section{Study characteristics}

The majority of the studies were conducted at a single site except for Edgren [29] which was carried out across 


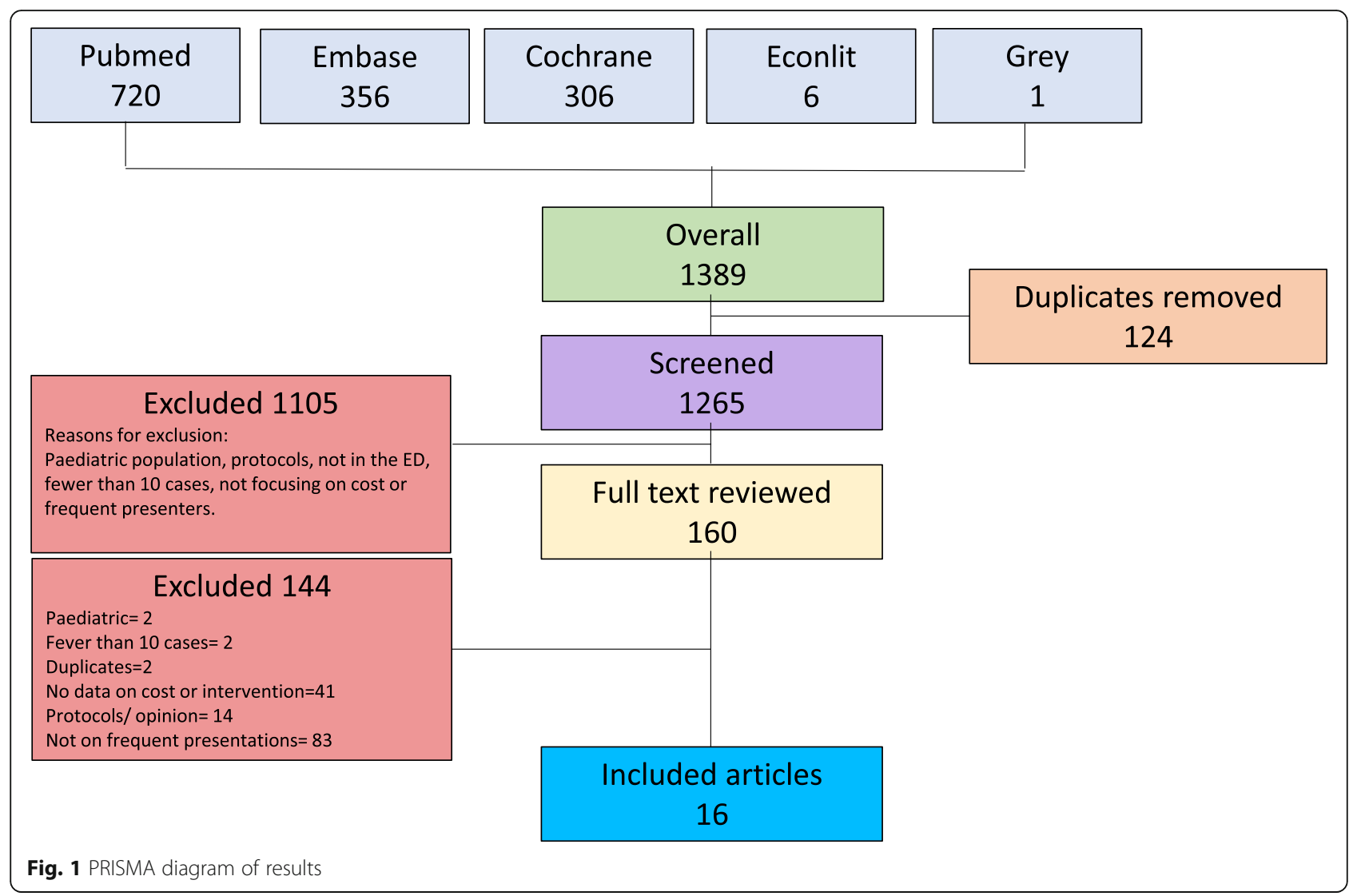

five counties in Sweden and Enard [31] which was carried out in nine emergency departments. One other study [3] used patients from an insurance database to assess costs. The majority of the studies included in the analysis are from the US. The findings from the US studies may have different implications from the Swedish and Australian studies as the US does not have a universal healthcare system. Therefore the cost savings identified in these studies could be for both health care services provided as well as individual out of pocket costs, which would be significantly less in a universal health care system.

The studies ranged in size from 36 [32, 33] to 14,140 [3] participants in an insurance scheme. All the studies were carried out between 1995 and 2015 with the majority being carried out after 2005 .

The interventions are described in the table but all were based on a case management approach. Seven of the studies had controls alongside the intervention group [3, 15, 28, 29, 34-37]. The majority of the studies were pre and post studies and were non-randomised. Only five $[15,28,29,35,38]$ of the studies were randomised and one of those was a pilot study [35].

\section{Definitions}

As seen previously [39] the definition of frequent presenter to the ED varied markedly. All the papers targeted 'frequent presenters' generally, rather than focusing on subgroups of frequent presenters such as the homeless or psychiatric services [40]. Table 2 provides a summary of the definitions used in the papers. These varied from 2 presentations per year [34] to more than 10 presentations per year [41]. Some papers simply identified patients "with the greatest number of visits" [33] or "who were known to use services in an unplanned manner" [30] but did not quantify the definition.

\section{Intervention outcomes}

Table 3 summarises the interventions and whether each study led to a reduction in ED use or cost. All of the included studies used a variant of a case management approach. Different names were used such as care coordination or acute care plans. The details varied from study to study but often included sessions with a social worker or nurse with referrals to specialist services and telephone follow up. Some studies included additional services such as mentoring and goal setting [30] or assistance with housing $[15,41,42]$. The majority of the studies yielded findings of decreased ED use and costs. However three of the studies found either mixed results [29], a decrease in ED use but not inpatient use [15] or a decrease in ED use but not in outpatient use. No 
Table 1 Study characteristics

\begin{tabular}{|c|c|c|c|c|c|}
\hline Study (Yr) & Country & Setting & Number of subjects in the study & $\begin{array}{l}\text { Intervention } \\
\text { period }\end{array}$ & Comparator \\
\hline $\begin{array}{l}\text { Crane } \\
(2012)\end{array}$ & USA & 200 bed not for profit hospital. & 36 (from initial group of 255) & $\begin{array}{l}\text { July 2009- } \\
\text { June } 2010\end{array}$ & $\begin{array}{l}\text { Pre and } \\
\text { post }\end{array}$ \\
\hline $\begin{array}{l}\text { DeHaven } \\
\text { (2012) }\end{array}$ & USA & $1 \mathrm{ED}$ in Dallas & 574 (265 intervention and 309 controls) & $\begin{array}{l}\text { April 2003- } \\
\text { July } 2004\end{array}$ & Controls \\
\hline $\begin{array}{l}\text { Edgren } \\
(2016)\end{array}$ & Sweden & 5 counties in Sweden. & $\begin{array}{l}\text { Group One used Zelen's design and had } 7280 \text { in intervention } \\
\text { group and } 3508 \text { in control group. Group two used RCT design } \\
\text { and had } 934 \text { in intervention group and } 459 \text { in control group. }\end{array}$ & $\begin{array}{l}\text { 2010- } \\
\text { March2014. }\end{array}$ & Controls \\
\hline $\begin{array}{l}\text { Enard } \\
(2013)\end{array}$ & USA & $\begin{array}{l}\text { Nine Memorial Hermann EDs in } \\
\text { the Houston area }\end{array}$ & $\begin{array}{l}13,642 \text { participants (1905 in intervention and 11,373 in control } \\
\text { group). }\end{array}$ & $\begin{array}{l}\text { Nov 2008- } \\
\text { April } 2011\end{array}$ & $\begin{array}{l}\text { Pre and } \\
\text { post }\end{array}$ \\
\hline $\begin{array}{l}\text { Grimmer- } \\
\text { Somers } \\
(2010)\end{array}$ & Australia & One metropolitan health region & 37 patients & $\begin{array}{l}18 \text { months } \\
\text { from } 2007 \text { to } \\
2009\end{array}$ & $\begin{array}{l}\text { Pre and } \\
\text { post }\end{array}$ \\
\hline $\begin{array}{l}\text { Grover } \\
(2018)\end{array}$ & USA & $\begin{array}{l}\text { ED community hospital with } 225 \\
\text { bed hospital in suburban area. }\end{array}$ & 158 in intervention. & $\begin{array}{l}\text { Oct 2013- } \\
\text { June } 2015\end{array}$ & $\begin{array}{l}\text { Pre and } \\
\text { post. }\end{array}$ \\
\hline $\begin{array}{l}\text { Hardin } \\
(2017)\end{array}$ & USA & $\begin{array}{l}\text { Inner city tertiary hospital. 80,000 } \\
\text { annual ED visits. }\end{array}$ & 339 in intervention & $\begin{array}{l}\text { Nov } 2012- \\
\text { Dec } 2015\end{array}$ & $\begin{array}{l}\text { Pre and } \\
\text { post }\end{array}$ \\
\hline $\operatorname{Lin}(2017)$ & USA & $\begin{array}{l}\text { Brigham and Women's hospital. } \\
\text { Large urban acaedemic medical } \\
\text { centre }\end{array}$ & 72 (36 in intervention and 36 in control) & $\begin{array}{l}\text { Oct 2014- } \\
\text { April } 2015\end{array}$ & Controls. \\
\hline $\begin{array}{l}\text { Murphy } \\
\text { (2013) }\end{array}$ & USA & $\begin{array}{l}\text { Regional medical and trauma } \\
\text { centre. } 644 \text { beds and 80,000 ED } \\
\text { visits per yr. }\end{array}$ & 141 (76 extreme and 65 frequent ED users) & $\begin{array}{l}\text { Jan } 2008- \\
\text { Dec } 2010\end{array}$ & $\begin{array}{l}\text { Pre and } \\
\text { post. }\end{array}$ \\
\hline $\begin{array}{l}\text { Navratil- } \\
\text { Strawn } \\
\text { (2014) }\end{array}$ & USA & $\begin{array}{l}\text { Patients enrolled in an insurance } \\
\text { scheme. }\end{array}$ & 14,140 (7070 participants and an equal number of controls) & $\begin{array}{l}\text { June-Nov } \\
2011\end{array}$ & Controls. \\
\hline $\begin{array}{l}\text { Okin } \\
(2000)\end{array}$ & USA & San Francisco General Hospital. & 53 patients. & $\begin{array}{l}\text { June } 1995- \\
\text { June } 1996\end{array}$ & $\begin{array}{l}\text { Pre and } \\
\text { post. }\end{array}$ \\
\hline $\begin{array}{l}\text { Reinius } \\
\text { (2012) }\end{array}$ & Sweden & $\begin{array}{l}\text { Karolinska University Hospital } \\
\text { with } 90,000 \text { visits per yr. }\end{array}$ & 268 patients (211 in intervention and 57 in control group). & $\begin{array}{l}\text { Sep 2010- } \\
\text { Sep } 2011\end{array}$ & Controls \\
\hline $\begin{array}{l}\text { Seaberg } \\
(2017)\end{array}$ & USA & $\begin{array}{l}\text { Urban ED with } 57,000 \\
\text { presentations per yr. }\end{array}$ & 318 (184 in intervention and 134 controls). & $\begin{array}{l}\text { Jan- June } \\
2015\end{array}$ & Controls. \\
\hline $\begin{array}{l}\text { Shumway } \\
\text { (2008) }\end{array}$ & USA & $\begin{array}{l}\text { San Francisco General Hospital. } \\
\text { Sole Level } 1 \text { trauma hospital in } \\
\text { the county. }\end{array}$ & 252 (167 in intervention and 85 to usual care) & $\begin{array}{l}\text { March } 1997 \\
\text { to Feb } 1999\end{array}$ & Controls. \\
\hline $\begin{array}{l}\text { Stokes- } \\
\text { Buzzelli } \\
(2010)\end{array}$ & USA & $\begin{array}{l}\text { Urban hospital with 95,000 ED } \\
\text { presentations per yr. }\end{array}$ & 36 patients & $\begin{array}{l}\text { June } 2005- \\
\text { July } 2007\end{array}$ & $\begin{array}{l}\text { Pre and } \\
\text { post }\end{array}$ \\
\hline $\begin{array}{l}\text { Tadros } \\
(2012)\end{array}$ & USA & One urban hospital. & 51 patients & $\begin{array}{l}\text { Dec 2006- } \\
\text { June } 2009\end{array}$ & $\begin{array}{l}\text { Pre and } \\
\text { post }\end{array}$ \\
\hline
\end{tabular}

The Evidence Project risk of bias tool [26] showed that the majority of the papers were cohort studies. Five of the studies randomly assigned participants. One study reported on follow up rates, in the other papers follow up was either not applicable because of study design or not reported. The table is included in the Additional file 1

'adverse events', such as costs being diverted to other areas were examined.

The magnitude of the change in costs and effects is captured at the bottom of Table 3. While there is heterogeneity in reporting, it was possible to summarise some of the degree of change across the studies as a result of the various interventions.

\section{Economic outcomes}

Table 4 summarises the main economic outcomes. All of the included studies examined cost from the healthcare system perspective. Though one of the papers [15] included 'cost effectiveness' in the title, the paper did not report an incremental cost effectiveness ratio (ICER). Two of the studies $[3,42]$ reported on return on investment (ROI). All of the studies included some form of cost analysis without analysis of effectiveness.

All of the papers in the review comment on the cost implications of the interventions and these are summarised in Table 4. It was unclear whether the costs reported in the studies incorporated the costs of the program. Crane with twice weekly meetings cost $\$ 66,000$ for the year for an intervention for 36 patients [32]. Grimmer- Sommers entailed an equivalent amount for 
Table 2 Frequent presenter definitions

\begin{tabular}{lll}
\hline Author & Year & Frequent Presenter' Definition \\
\hline Crane & 2012 & $\geq 6$ visits/ year \\
DeHaven & 2012 & $\geq 2$ visits/ year \\
Edgren & 2016 & $\geq 3$ visits in previous 6 months \\
Enard & 2013 & Extracted data from $>5$ visits pre intervention period. \\
Grimmer-Somers & 2010 & Individuals known to use public hospital ED services in an unplanned manner. \\
Grover & 2018 & $\geq 10$ visits in 12 months, \\
& & $\geq 4$ visits in 6 months, month or concerned ED use. \\
Hardin & $\geq 3$ visit/ year \\
Lin & Patients with the most ED visits in the previous month and previous year. \\
Murphy & 2017 & Frequent $=3-11$ visits per year, \\
Navratil-Strawn & 2017 & Extreme $=\geq 12$ visits/year preceding year of enrolment. \\
Okin & 2013 & $\geq 3$ visits/ year in the previous 12 months \\
Reinius & $\geq 5$ visits/ year \\
Seaberg & $\geq 3$ visits during 6 months before inclusion. \\
Shumway & 2014 & $\geq 5$ visits/ year \\
Stokes-Buzzelli & 2000 & $\geq 5$ visits/ year \\
Tadros & 2012 & Patients with the most ED visits. \\
\hline
\end{tabular}

37 patients $\$ 63,434$ [30]. Lin reported 36 people in the intervention arm with an annualised cost of the program of $\$ 55,115$ [35], though it is unclear how often the patients received the intervention. The program by Murphy cost $\$ 265,680$ for the year [43] for a broad multidisciplinary program for 141 patients. Okin reported a total cost of $\$ 296,738$ for 53 patients over one year for a comprehensive case management program. Navaratil-Strawn included the large dataset of insurance users and cost $\$ 2.75$ million to implement [3].

Other papers reported a percentage change or decrease as a result of the program. Crane [32] reported hospital charges dropped from $\$ 1167$ to $\$ 230$ per patient per month. Dehaven [34] reported direct hospital costs decreased by $60 \%$ and indirect costs by $50 \%$. Grover [44] reported a $41 \%$ reduction in hospital charges. Hardin [45] reported $45 \%$ decline in gross charges and $47 \%$ reduction in direct expenses. Lin [35] found a 15\% reduction in ED direct costs as a result of the intervention. Reinus [28] reported a $45 \%$ decrease in per patient hospital costs. Seaberg [38] found a decrease in overall healthcare costs of $26 \%$ in the intervention group (though the control group also saw a reduction of $17.5 \%)$. Stokes- Buzzelli [33] reported a $24 \%$ decrease in ED charges and Tadros [41] a 32.1\% decrease in charges.

Costs were reported in different ways which made it difficult to compare across studies. Some papers [32] reported a decrease in cost per patient per month as a result of the intervention. Dehaven [34] and Hardin [45] reported a decrease in direct (wages, salaries, materials) and indirect costs (administration costs, insurance and maintenance costs) as a result of the intervention. While Grover [44] reported a total decrease in programme costs which was due to a $49 \%$ reduction in visits attributable to the intervention. The cost saving came from the result of fewer patients presenting to the ED and needing investigations and admission. Others $[3,42]$ reported a return on investment (ROI) which were similar in both studies, \$1.24 [3] and \$1.44 [42]. This was measured by dividing the total program savings by the total program costs. Overall however, as there were multiple differences in settings and methodology, comparisons of findings across the studies need to be made with caution.

\section{Discussion}

This review showed that interventions targeting frequent presenters in emergency departments can have an impact in saving health care costs. Of the 16 papers included in the review, all of them reported on costs but there is no data on cost effectiveness. Future studies should standardise the way that costing information is reported so that costs may be compared between interventions within the same healthcare system. For example reporting costs in individual units such as for staff, medications and investigations. The CHEERS [46] statement seeks to standardise the way in which economic evaluations are reported.

The study by Edgren [29] stands apart from the other interventions as it showed mixed results. Patients were 


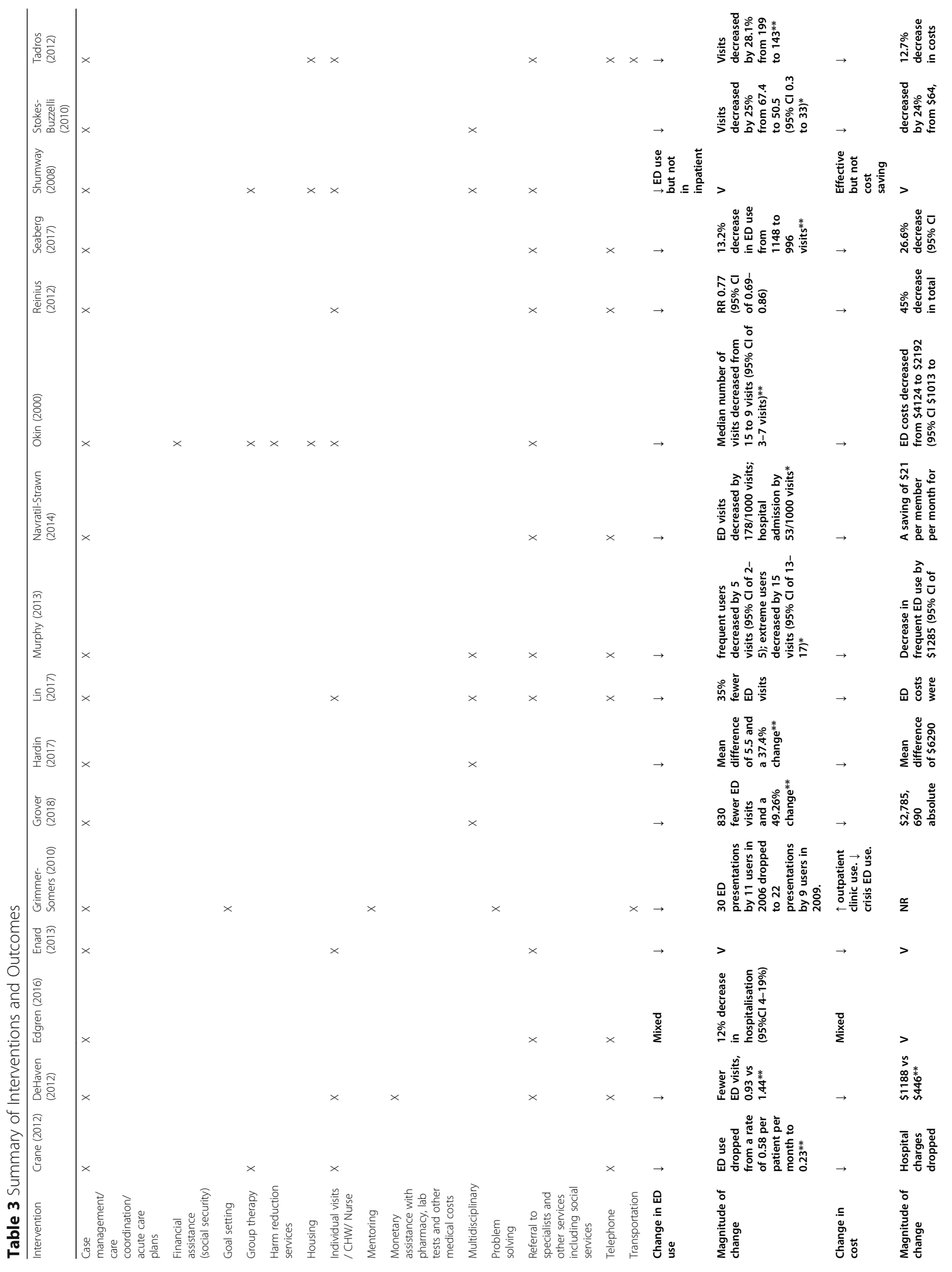




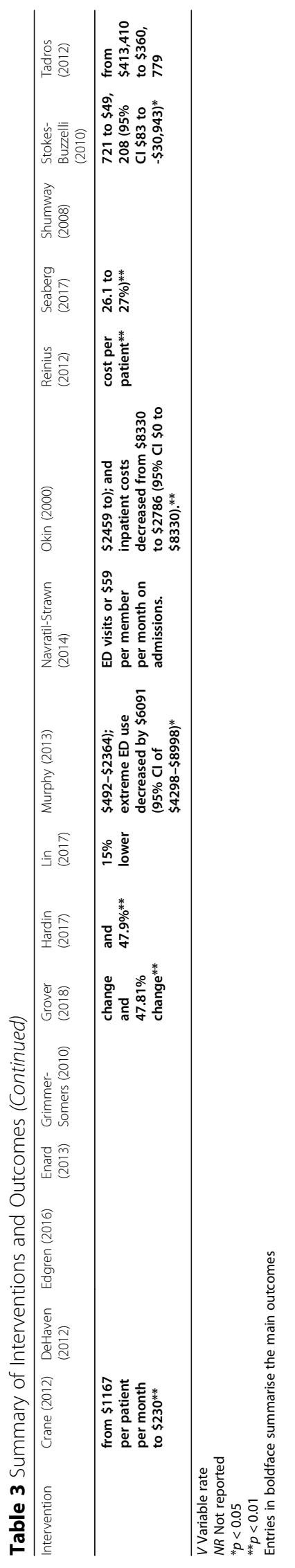


Table 4 Economic outcomes

\begin{tabular}{|c|c|c|c|c|c|c|}
\hline Study $(Y r)$ & Country & Social Economic Background & Perspective & $\begin{array}{l}\text { Cost variable included in } \\
\text { analysis }\end{array}$ & $\begin{array}{l}\text { Type of } \\
\text { economic } \\
\text { evaluation }\end{array}$ & Outcome \\
\hline $\begin{array}{l}\text { Crane } \\
\text { (2012) }\end{array}$ & USA & Low income, uninsured. & Healthcare & $\begin{array}{l}\text { Hospital charges ( } \$ 1167 \text { per } \\
\text { month pre-intervention, } \$ 230 \\
\text { post-intervention); cost of pro- } \\
\text { gram }(\$ 66 \mathrm{~K})\end{array}$ & $\begin{array}{l}\text { Cost } \\
\text { analysis }\end{array}$ & $\begin{array}{l}\text { ED use dropped by } 0.25 \text { per } \\
\text { patient per month } 0.23 \text { and } \\
\text { hospital charges dropped from } \\
\$ 1167 \text { per patient per month to } \\
\$ 230 \text {. }\end{array}$ \\
\hline $\begin{array}{l}\text { DeHaven } \\
\text { (2012) }\end{array}$ & USA & Uninsured & Healthcare & $\begin{array}{l}\text { Indirect costs (sum of costs for } \\
\text { all ED visits for the year, } \\
\text { includes fixed costs related to } \\
\text { building maintenance, staffing } \\
\text { and utilities) }\end{array}$ & $\begin{array}{l}\text { Cost } \\
\text { analysis }\end{array}$ & $\begin{array}{l}\text { Intervention enrolees of the } \\
\text { PAD program had significantly } \\
\text { fewer ED visits ( } 0.93 \text { vs } 1.44) \text {. } \\
\text { Direct hospital costs around } \\
60 \% \text { less ( } \$ 1188 \text { vs } 446) \text {. Indirect } \\
\text { costs } 50 \% \text { less ( } \$ 313 \text { vs } \$ 692) \text {. }\end{array}$ \\
\hline $\begin{array}{l}\text { Edgren } \\
\text { (2016) }\end{array}$ & Sweden & $\begin{array}{l}\text { "Screening aimed to identify } \\
\text { patients who seemed to be } \\
\text { lacking in health literacy, sought } \\
\text { care at an improper level, or } \\
\text { from too many providers". }\end{array}$ & Healthcare & $\begin{array}{l}\text { Costs of conducting } \\
\text { maintenance activities ( } \$ 13, \\
950.42) \text {, total program cost }(\$ 54, \\
284.31 \text { ). Per-client discretionary } \\
\text { costs for transport, equipment, }\end{array}$ & $\begin{array}{l}\text { Cost } \\
\text { analysis }\end{array}$ & $\begin{array}{l}\text { The traditional design showed } \\
\text { an overall } 12 \% \text { decreased rate } \\
\text { of hospitalization, which was } \\
\text { mostly driven by effects in the } \\
\text { last year. }\end{array}$ \\
\hline
\end{tabular}
costs for transport, equipment, medications and interpreters (\$250 per person).

Enard

(2013)

USA

Publically insured (Medicaid) uninsured (self pay), or covered by a local public health benefit that subsidises medical costs for eligible residents.

Grimmer- Australia Unplanned ED use, crisis Somers inpatient admission, poor (2010) attendance at primary health and/ or outpatient clinics, unmanaged chronic disease, medication misuse, vulnerable social circumstances.

Grover

USA

(2018)

Patients who demonstrated a propensity for future problematic ED encounters such as violence in the ED or prescription forgery.

Hardin USA Patients who would benefit

(2017) from a Complex Care Map

Lin (2017) USA NR

Murphy USA NR

(2013)

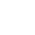

Navratil- USA Insurance scheme

Strawn

(2014)

Okin
Healthcare

Prior to enrolment: ED charges $(\$ 8,453,761)$, inpatient charges $(\$ 8,453,761)$. Post-intervention: ED charges $(\$ 3,041,473)$ and inpatient charges $(\$ 5,405,175)$.

Healthcare

Gross charges and expenses, ED Cost service charges and expenses, IP analysis service charges and expenses, outpatient service charges and expenses.

Healthcare

Average direct costs per patient for intervention and control groups.

Cost analysis

The savings associated with reduced PCR-ED visits were greater than the cost to implement the navigation program.

Staff spent $34 \mathrm{~h}$ with each client, costing \$1700 each. Crisis ED and inpatient admissions decreased. Planned outpatient clinic use increased.

ED and hospital charges decreased by 5.8 million dollars (41\% reduction)

Healthcare

Direct treatment costs (wages, salaries, materials): indirect costs (those incurred as part of the production process (e.g. admin costs, maintenance costs)

Healthcare Hospital service costs

Healthcare Health care system costs - total and fire costs for transport or nondepartment transport responses based on predicted or actual call volume. treatment costs (\$1285) leading

Healthcare Hospital inpatient and Cost outpatient Medicare costs (not analysis charges). ED physician costs not and ROI included in this study.

Healthcare Medical inpatient costs, psychiatric emergency costs, psychiatric inpatient costs, medical outpatient costs, physicians' professional fee costs, non EDCM costs
Cost analysis

Cost analysis

Frequent and extreme users decreased in ED visits (5 and 15 respectively) and direct to significant hospital cost savings.

ED mean visits decreased $43 \%$, inpatient admission decreased $44 \%$. Gross charges decreased $45 \%$, direct expenses decreased $47 \%$.

Average ED direct costs 15\% ower for intervention patients. Average inpatient costs per parerage inpatient

Participants had greater reduction in $\mathrm{ED}$ visits $(p=0.003)$ and hospital admissions ( $p=$ 0.002 ) and increased office visits $(p=<0.001)$. ROI of 1.24 .

Cost Median number of ED visits analysis decreased from 15 to $9(p<0.1)$ and $\mathrm{ROI}$ and median inpatient costs decreased from $\$ 4330$ to $\$ 2786$ $(p<0.1)$. ROI of $\$ 1.44$. 
Table 4 Economic outcomes (Continued)

\begin{tabular}{|c|c|c|c|c|c|c|}
\hline Study (Yr) & Country & Social Economic Background & Perspective & $\begin{array}{l}\text { Cost variable included in } \\
\text { analysis }\end{array}$ & $\begin{array}{l}\text { Type of } \\
\text { economic } \\
\text { evaluation }\end{array}$ & Outcome \\
\hline & & $\begin{array}{l}\text { without meical insurance to } \\
\text { medicaid. }\end{array}$ & & & & \\
\hline $\begin{array}{l}\text { Reinius } \\
\text { (2012) }\end{array}$ & Sweden & NR & Healthcare & $\begin{array}{l}\text { Ambulance and hospital } \\
\text { charges as proxy for cost of } \\
\text { care. No evaluation of individual } \\
\text { insurance status or } \\
\text { reimbursements. }\end{array}$ & $\begin{array}{l}\text { Cost } \\
\text { analysis }\end{array}$ & $\begin{array}{l}\text { Intervention reduced the total } \\
\text { healthcare costs for per person } \\
\text { hospital admissions by } 45 \% \text {. }\end{array}$ \\
\hline $\begin{array}{l}\text { Seaberg } \\
(2017)\end{array}$ & USA & NR & Healthcare & $\begin{array}{l}\text { Total healthcare cost, primary } \\
\text { and secondary care visit costs } \\
\text { for outpatient care }\end{array}$ & $\begin{array}{l}\text { Cost } \\
\text { analysis }\end{array}$ & $\begin{array}{l}\text { ED visits decreased overall with } \\
\text { a larger decrease in the } \\
\text { intervention group (by 13.2\%) } \\
\text { compared to the control group } \\
\text { (by } 4.5 \% \text { ). }\end{array}$ \\
\hline $\begin{array}{l}\text { Shumway } \\
\text { (2008) }\end{array}$ & USA & $\begin{array}{l}\text { Subjects had psychosocial } \\
\text { problems that could be } \\
\text { addressed with case } \\
\text { management (problems with } \\
\text { housing, medical care, } \\
\text { substance abuse, mental health } \\
\text { disorders or financial } \\
\text { entitlements). }\end{array}$ & Healthcare & $\begin{array}{l}\text { Total costs of the intervention } \\
\text { and total cost per person }\end{array}$ & $\begin{array}{l}\text { Cost } \\
\text { analysis }\end{array}$ & $\begin{array}{l}\text { Reductions in ED use and cost } \\
\text { did not translate to reductions } \\
\text { in inpatient use, which } \\
\text { represent a larger proportion of } \\
\text { total hospital service use. }\end{array}$ \\
\hline $\begin{array}{l}\text { Stokes- } \\
\text { Buzzelli } \\
\text { (2010) }\end{array}$ & USA & $\begin{array}{l}89 \% \text { of the study population } \\
\text { had substance abuse issues. }\end{array}$ & Healthcare & ED charges & $\begin{array}{l}\text { Cost } \\
\text { analysis }\end{array}$ & $\begin{array}{l}\text { ED charged decreased by } 24 \% \\
\text { (from } \$ 64,721 \text { to } \$ 49,208) \text {. The } \\
\text { number of lab studies ordered } \\
\text { decreased by } 28 \% \text {. The number } \\
\text { of average ED visits decreased } \\
\text { by } 25 \% \text {. }\end{array}$ \\
\hline $\begin{array}{l}\text { Tadros } \\
(2012)\end{array}$ & USA & NR & Healthcare & $\begin{array}{l}\text { Total healthcare costs for } \\
\text { hospital admissions }\end{array}$ & $\begin{array}{l}\text { Cost } \\
\text { analysis }\end{array}$ & $\begin{array}{l}\text { Pre-hospital based case } \\
\text { management system is effective } \\
\text { in decreasing transport by } \\
\text { frequent presenters but had } \\
\text { only a limited impact on use of } \\
\text { hospital services. }\end{array}$ \\
\hline
\end{tabular}

recruited from five counties in Sweden and different study designs were used (Zelen's and randomised controlled trial (RCT)) "depending on local requirements and preferences" [29]. The study arms were analysed and reported separately. There was no difference in the first two years but decreases in the number of days in hospital and average cost were found in the third year. However, overall there was "no significant difference in either total healthcare costs or the number of days in hospital" [29].

Despite using a mix of interventions across the studies, most of the approaches led to a decrease in ED presentations and costs. A case management approach which linked patient services was the standard model employed which generally included contact with a nurse or community health worker, referral to services and telephone follow up. Other approaches included financial assistance in the form of linkages to social security entitlements [42], financial reimbursement for medical (mainly laboratory and pharmacy) services [34], goal setting [30] and housing support $[15,41,42]$.

The level of patient interaction varied across the studies. Crane included twice weekly appointments with a multidisciplinary team [32], while Dehaven [34] outlined monthly meetings with a community health worker. The intervention by Reinius [28] included weekly or biweekly contact with patients. While the study by Seaberg [38] followed patients up at 2 weeks and 12 months from initial contact. In Stokes-Buzzelli [33] patients were contacted at least monthly. The other studies in the review did not specifically mention the frequency of patient contact. The studies which incorporated more frequent contact with patients still showed a decrease in ED use and cost.

Six of the interventions included a multidisciplinary team [15, 33, 35, 43-45]. The remaining interventions were led by nurses, social workers or community care coordinators. Regardless of the way the intervention was carried out, it tended to decrease ED use. Furthermore a multidisciplinary approach while likely more expensive to carry out, apart from Shumway [15] still led to cost savings. This could be as a result of multidisciplinary committees being formed by individuals already employed by the hospital, thereby not increasing program costs as the staff are already employed. Usually this 
would be included as a cost as it represents an opportunity cost as these staff members could be doing something else with their time.

An advantage of these case management programs is that patients can be assessed away from a busy and often over crowded emergency department. This could potentially lead to better management and fewer repeat investigations, which would likely be contributing to increasing costs.

This study is different to others in that it draws together the evidence of costing interventions for frequent presentations to the ED. Some papers outlining interventions have included some information regarding cost or cost effectiveness but as far as we are aware there has been no previous systematic literature review summarising the cost implications of interventions for frequent presenters. Given the mounting budgetary pressures on health systems worldwide, these findings provide guidance for health care decision makers addressing the financial pressures exerted in the delivery of emergency room care. The second strength was that it was a systematic review following PRISMA guidelines which were rigorous.

There were however a few limitations of this study. First, most of the studies were carried out in the US. The findings from the US setting may not translate directly to other countries with a different health care system. The drivers for reducing frequent presentations to the ED in the US (a user pays largely privatised system) would be different to a single payer system like that of the UK or Australia. Second, the majority of the studies included a simple cost analysis rather than cost effectiveness studies and may overlook presentations to other health care settings including allied health and potential health outcomes resulting from reduced ED presentations. Third, fewer than half of the studies used controls. The majority of the studies were pre and post with the same cohort and therefore may not adequately account for secular trends or regression to the mean [13, 47]. Another limitation is the absence of a clear definition of 'frequent presenter'. A definition of 'frequent presenter' is lacking in the literature. As with medicine, it is important to define the problem in order to find a solution, yet there is no consensus in the literature. This is something the authors are currently working on in other research they are undertaking and hope to develop an inclusive and definitive classification that can be widely used.

\section{Conclusion}

The main conclusion to draw from this study are that all of the interventions have an element of case management, most of which were shown to be cost saving. A range of interventions based on case management approaches was adopted and no difference was found. The cost savings were reported in different ways across the studies, either in the number of ED presentations, direct or indirect hospital costs. Future research should focus on conducting cost-effectiveness analyses to aid decisions about whether an intervention should be offered to frequent presenters to the ED. Such research would also shed light on the clinical effectiveness of the different approaches taken and potentially provide an economic case for funding such programs. Despite the research in this area there is no definitive approach or program for this population group. A cost effectiveness study which assesses effectiveness alongside costs would do much to add to the current evidence on the best methods to assist this population group.

\section{Supplementary information}

Supplementary information accompanies this paper at https://doi.org/10. 1186/s12873-019-0296-4

Additional file 1: Risk of Bias Assessment

\section{Abbreviations}

CBT: Cognitive behaviour therapy; ED: Emergency department; ICER: Incremental cost effectiveness ratio; RCT: Randomised control trial; ROI: Return on investment

\section{Acknowledgements}

Not applicable.

\section{Authors' contributions}

VK planned the study, conducted the review, extracted data and drafted the paper. JS was the second reviewer, extracted data and commented on earlier drafts. SJ gave feedback on the planning of the study and on earlier drafts. MD gave feedback on earlier drafts. TL gave feedback on the planning of the study and on earlier drafts. All authors have read and approved the final manuscript.

\section{Funding}

VK is supported by the UNSW Scientia PhD Scholarship. TL is supported by an NHMRC Early Career Fellowship (APP1141392) and a Heart Foundation Postdoctoral Fellowship (award ID 101956). SJ is supported by an NHMRC Principal Research Fellowship (APP1119443). The funding bodies had no role in the design of the study, collection, analysis, interpretation of data or writing of the manuscript.

Thomas Lung is supported by an NHMRC Early Career Fellowship (APP1141392) and a Heart Foundation Postdoctoral Fellowship (award ID 101956)

\section{Availability of data and materials}

The datasets used and/or analysed during the current study are available from the corresponding author on reasonable request.

Ethics approval and consent to participate Not applicable.

Consent for publication

Consent form has been signed.

Competing interests

The authors declare that they have no competing interests.

\section{Author details}

${ }^{1}$ The George Institute for Global Health, UNSW Sydney, Level 5/1 King St Newtown NSW, Sydney 2042, Australia. ²Emergency Department, Royal 
Prince Alfred Hospital, Sydney, Australia. ${ }^{3}$ Faculty of Medicine and Health, University of Sydney, Sydney, NSW, Australia. ${ }^{4}$ The Australian Human Rights Institute, UNSW Sydney, Sydney, Australia.

Received: 22 June 2019 Accepted: 17 December 2019

Published online: 30 December 2019

\section{References}

1. Locker TE, Baston S, Mason SM, Nicholl J. Defining frequent use of an urban emergency department. Emerg Med J : EMJ. 2007;24(6):398-401.

2. Althaus F, Paroz S, Hugli O, Ghali WA, Daeppen JB, Peytremann-Bridevaux I, et al. Effectiveness of interventions targeting frequent users of emergency departments: a systematic review. Annals Emerg Med. 2011;58(1):41-52.e42.

3. Navratil-Strawn JL, Hawkins K, Wells TS, Ozminkowski RJ, Hartley SK, Migliori $\mathrm{RJ}$, et al. An emergency room decision-support program that increased physician office visits, decreased emergency room visits, and saved money. Popul Health Manage. 2014;17(5):257-64.

4. Okuyemi KS, Frey B. Describing and predicting frequent users of an emergency department. J Assoc Acad Minor Phys : Official Publication Assoc Acad Minor Phys. 2001;12(1-2):119-23.

5. Markham D, Graudins A. Characteristics of frequent emergency department presenters to an Australian emergency medicine network. BMC Emerg Med. 2011;11:21.

6. Peddie S, Richardson S, Salt L, Ardagh M. Frequent attenders at emergency departments: research regarding the utility of management plans fails to take into account the natural attrition of attendance. N Z Med J. 2011; 124(1331):61-6

7. Spillane LL, Lumb EW, Cobaugh DJ, Wilcox SR, Clark JS, Schneider SM. Frequent users of the emergency department: can we intervene? Acad Emerg Med Off J Soc Acad Emerg Med. 1997;4(6):574-80.

8. Ruger JP, Richter CJ, Spitznagel EL, Lewis LM. Analysis of costs, length of stay, and utilization of emergency department services by frequent users: implications for health policy. Acad Emerg Med Off J Soc Acad Emerg Med. 2004;11(12):1311-7.

9. LaCalle $\mathrm{E}$, Rabin E. Frequent users of emergency departments: the myths, the data, and the policy implications. Ann Emerg Med. 2010;56(1):42-8.

10. Sun BC, Burstin HR, Brennan TA. Predictors and outcomes of frequent emergency department users. Acad Emerg Med Off J Soc Acad Emerg Med. 2003;10(4):320-8.

11. Curran GM, Sullivan G, Williams K, Han X, Allee E, Kotrla KJ. The association of psychiatric comorbidity and use of the emergency department among persons with substance use disorders: an observational cohort study. BMC Emerg Med. 2008;8:17

12. Minassian A, Vilke GM, Wilson MP. Frequent emergency department visits are more prevalent in psychiatric, alcohol abuse, and dual diagnosis conditions than in chronic viral illnesses such as hepatitis and human immunodeficiency virus. J Emerg Med. 2013;45(4):520-5.

13. Mandelberg JH, Kuhn RE, Kohn MA. Epidemiologic analysis of an urban, public emergency department's frequent users. Acad Emerg Med Off J Soc Acad Emerg Med. 2000;7(6):637-46.

14. Peppe E, Mays J, Chang H. Characteristics of frequent emergency department users. Henry J Kaiser Family Foundation 2007. https://www.kff. org/wp-content/uploads/2013/01/7696.pdf.

15. Shumway M, Boccellari A, O'Brien K, Okin RL. Cost-effectiveness of clinical case management for ED frequent users: results of a randomized trial. Am J Emerg Med. 2008;26(2):155-64

16. Baker M, Stallard J, Gibson S. A PILOT PROJECT TARGETING FREQUENT ATTENDERS AT THE EMERGENCY DEPARTMENT WITH MEDICALLY UNEXPLAINED SYMPTOMS. Emerg Med J : EMJ. 2013;30:866.

17. Andren $\mathrm{KG}$, Rosenqvist U. Heavy users of an emergency department: psycho-social and medical characteristics, other health care contacts and the effect of a hospital social worker intervention. Soc Sci Med (1982). 1985; 21(7):761-70.

18. Australian Institiutue of Health and Welfare. Australia's Health 2018 in Brief. 2018

19. Gulacti U, Lok U, Celik M, Aktas N, Polat H. The ED use and non-urgent visits of elderly patients. Turk J Emerg Med. 2016;16(4):141-5.

20. Australian Institute of Health and Welfare. Emergency department care 2016-17: Australian hospital statistics 2017 [updated 29 Nov 2017 Available from: https://www.aihw.gov.au/reports/hospitals/ahs-2016-17-emergencydepartment-care/contents/summary.
21. Agency for Healthcare Research and Quality. Trends in Emergency Department Visits 2006-2014 2017 [Available from: https://www.hcup-us. ahrq.gov/reports/statbriefs/sb227-Emergency-Department-Visit-Trends.pdf.

22. Australian Institute of Health and Welfare. Emergency Department Care 2017-2018: Australian Hospital Statistics. In: . p. 2018.

23. Hwang SW, Chambers C, Chiu S, Katic M, Kiss A, Redelmeier DA, et al. A comprehensive assessment of health care utilization among homeless adults under a system of universal health insurance. Am J Public Health. 2013;103(Suppl 2):S294-301.

24. Pitts SR, Carrier ER, Rich EC, Kellermann AL. Where Americans get acute care: increasingly, it's not at their doctor's office. Health Aff (Project Hope). 2010; 29(9):1620-9.

25. Moher D, Liberati A, Tetzlaff J, Altman DG. Preferred reporting items for systematic reviews and meta-analyses: the PRISMA statement. PLoS Med. 2009:6(7):e1000097.

26. Kennedy CE, Fonner VA, Armstrong KA, Denison JA, Yeh PT, O'Reilly KR, et al. The evidence Project risk of bias tool: assessing study rigor for both randomized and non-randomized intervention studies. Syst Rev. 2019;8(1):3.

27. Ferrari R. Writing narrative style literature reviews. Eur Med Writer's Associ. 2015;24(4):230-5.

28. Reinius P, Johansson M, Fjellner A, Werr J, Ohlen G, Edgren G. A telephonebased case-management intervention reduces healthcare utilization for frequent emergency department visitors. Eur J Emerg Med : Official J Eur Soc Emerg Med. 2013;20(5):327-34.

29. Edgren G, Anderson J, Dolk A, Torgerson J, Nyberg S, Skau T, et al. A case management intervention targeted to reduce healthcare consumption for frequent emergency department visitors: results from an adaptive randomized trial. Eur J Emerg Med. 2016:23(5):344-50.

30. Grimmer-Somers K, Johnston K, Somers E, Luker J, Alemao LA, Jones D. A holistic client-centred program for vulnerable frequent hospital attenders: cost efficiencies and changed practices. Aust N Z J Public Health. 2010;34(6):609-12

31. Enard KR, Ganelin DM. Reducing preventable emergency department utilization and costs by using community health workers as patient navigators. J Healthc Manag Am Coll Healthc Exec. 2013;58(6):412-27 discussion 28.

32. Crane S, Collins L, Hall J, Rochester D, Patch S. Reducing utilization by uninsured frequent users of the emergency department: combining case management and drop-in group medical appointments. J Am Board Fam Med : JABFM. 2012;25(2):184-91.

33. Stokes-Buzzelli S, Peltzer-Jones JM, Martin GB, Ford MM, Weise A. Use of health information technology to manage frequently presenting emergency department patients. West J Emerg Med. 2010;11(4):348-53.

34. DeHaven $M$, Kitzman-Ulrich H, Gimpel N, Culica D, O'Neil L, Marcee A, et al. The effects of a community-based partnership, Project Access Dallas (PAD), on emergency department utilization and costs among the uninsured. J Public Health (Oxford, England). 2012:34(4):577-83.

35. Lin MP, Blanchfield BB, Kakoza RM, Vaidya V, Price C, Goldner JS, et al. EDbased care coordination reduces costs for frequent ED users. Am J Manag Care. 2017;23(12):762-6.

36. Peppe E, Mays E, Change H, Becker E, Dijulio B. Characteristics of Frequent Emergency Department Uses, Henry J Kaiser Family Foundation, \#7696, Menlo Park, California. 2007.

37. Seaberg D, Elseroad S, Dumas M, Mendiratta S, Whittle J, Hyatte C, et al. Patient navigation for patients frequently visiting the emergency department: a randomized, controlled trial. Acad Emerg Med Off J Soc Acad Emerg Med. 2017:24(11):1327-33.

38. Seaberg D, Elseroad S, Dumas M, Mendiratta S, Whittle J, Hyatte C, et al. Patient navigation for patients frequently visiting the emergency department: a randomized, controlled trial. Acad Emerg Med. 2017.

39. Moe J, Kirkland S, Ospina MB, Campbell S, Long R, Davidson A, et al. Mortality, admission rates and outpatient use among frequent users of emergency departments: a systematic review. Emerg Med J : EMJ. 2016; 33(3):230-6

40. Pasic J, Russo J, Roy-Byrne P. High utilizers of psychiatric emergency services. Psychiatric Serv (Washington, DC). 2005:56(6):678-84.

41. Tadros AS, Castillo EM, Chan TC, Jensen AM, Patel E, Watts K, et al. Effects of an emergency medical services-based resource access program on frequent users of health services. Prehosp Emerg Care : Official J Natl Assoc EMS Physicians and Natl Assocof State EMS Dir. 2012;16(4):541-7.

42. Okin RL, Boccellari A, Azocar F, Shumway M, O'Brien K, Gelb A, et al. The effects of clinical case management of hospital service use among ED frequent users. Am J Emerg Med. 2000;18(5):603-8. 
43. Murphy SM, Neven D. Cost-effective: emergency department care coordination with a regional hospital information system. J Emerg Med. 2014;47(2):223-31.

44. Grover CA, Sughair J, Stoopes S, Guillen F, Tellez L, Wilson TM, et al. Case management reduces length of stay, charges, and testing in emergency department frequent users. West J Emerg Med. 2018;19(2):238-44.

45. Hardin L, Kilian A, Muller L, Callison K, Olgren M. Cross-continuum tool is associated with reduced utilization and cost for frequent high-need users. West J Emerg Med. 2017;18(2):189-200.

46. Husereau D, Drummond M, Petrou S, Carswell C, Moher D, Greenberg D, et al. Consolidated health economic evaluation reporting standards (CHEERS) statement. Int J Technol Assess Health Care. 2013;29(2):117-22.

47. Fuda KK, Immekus R. Frequent users of Massachusetts emergency departments: a statewide analysis. Ann Emerg Med. 2006;48(1):9-16

\section{Publisher's Note}

Springer Nature remains neutral with regard to jurisdictional claims in published maps and institutional affiliations.

Ready to submit your research? Choose BMC and benefit from:

- fast, convenient online submission

- thorough peer review by experienced researchers in your field

- rapid publication on acceptance

- support for research data, including large and complex data types

- gold Open Access which fosters wider collaboration and increased citations

- maximum visibility for your research: over $100 \mathrm{M}$ website views per year

At BMC, research is always in progress.

Learn more biomedcentral.com/submissions 